\title{
“Fun, Fun, Fun": Types of Fun, Attitudes to Fun, and their Relation to Personality and Biographical Factors
}

\section{C. McManus, Adrian Furnham}

Research Department of Clinical, Educational and Health Psychology, Division of Psychology and Language Sciences, University College London, London, UK.

Email: i.mcmanus@ucl.ac.uk

Received May $16^{\text {th }}$, 2010; revised June $29^{\text {th }}, 2010$; accepted June $31^{\text {st }}, 2010$.

\begin{abstract}
This study explores the psychologically neglected concept of fun, a concept that contributes strongly to many people's perceptions of quality in life, and looks both at the different types of behaviour that people regard as fun and the attitudes that people have towards fun. Through focus groups and interviews, a 40-item attitude questionnaire was developed and completed by 1100 people. Factor analysis identified five attitudinal factors, which were labelled as "Fun involving risk-taking"; "Fun dependent on fun people"; "Fun causing happiness"; "Money needed to have fun"; and "Spontaneity as fun". These different factors showed different patterns of correlation with demographic and personality measures. The different types of situation that people described as fun were assessed by asking participants to use an adjective check-list to describe a situation they had found to be fun. Factor analysis identified five types of fun ("Sociability", "Contentment", "Achievement", "Sensual" and "Ecstatic"), the different types correlating systematically with participants' demography, personality and attitudes to fun. Although often used as if it were a single concept, "fun" is actually a complex phenomenon that has different meanings for different types of people.
\end{abstract}

Keywords: Fun, Big Five, Personality, Demography, Leisure Activities

\section{Introduction}

If searching for an epithet for the Zeitgeist of the opening years of the twenty-first century, then the word "fun" might well be suitable. Typing "fun" into the search engine Google in finds no less than 662,000,000 websites (and in comparison, "sex" achieved only 655,000,000 hits; all search engine figures at August 2009). Likewise, Amazon.com finds 607,923 results for books containing the word (and Amazon.co.uk found 30,659 titles), with the best-seller for adults being 301 ways to have fun at work, which perhaps typifies the genre.. The all- pervasive nature of fun in advanced modern societies such as the United States has been eloquently summarised by Bryant and Forsyth [1]:

"The United States is a society that has become almost pathologically obsessed with fun. Fun is a source of enjoyment, pleasure, amusement, and even excitement. ... Today the pursuit of happiness (and fun) is, in effect, the national quest, and this goal permeates our lives. ... The pursuit of fun has a place of dominant centrality in our daily lives, but fun seeking is not a compartmentalized area of our cultural fabric. Rather, it is constituent to almost every aspect of our daily lives. Fun seeking is very much integrated into our entire culture and in our daily cycle of life - home, work, rest, maintenance, and even sleep. Our hedonistic quest has become a deified entity of its own - the Fun God, as it were.”

Bryant and Forsyth's phrase "the Fun God" is reminiscent of Psychology and "the great god fun", by AE (“Tajar”) Hamilton [2], a book whose title makes one aware of the near total absence of serious interest of psychologists in the nature of fun (although the book itself has little serious analysis of the concept). A search of PsycINFO found only 246 pieces with "fun" in the title, of which the vast majority were mostly concerned with using fun as an intervening or outcome variable in education, health education or other activities (e.g. [3-8] or with topics such as helping academics to write for a general audience [9] or carry out structural equation modelling [10]. 
Conceptualising fun is not straightforward, in part because of the number of synonyms for fun such as amusement, enjoyment and entertainment. and in addition every generation seems to produce its own synonyms for fun, such as "far out" or "cool". Fun is therefore a complex word with multiple meanings referring to affective and motivational properties, People seek out fun activities but respond to situations with a sense of fun, so that fun can be an activity, a state, or a trait. Fun can be used both as a motivational concept: "to want to have fun" or a trait concept, "They are a fun-loving sort of person", but it is most often described as the property of a behavioural repertoire or social situation: "The dinner party was fun". The opposite of fun is usually thought of as tedious, boring, dull, or other synonyms. The fact that psychologists almost never use the word makes it difficult to offer a definition that clearly distinguishes it from other positive emotional elicitors, triggers or states. A principle aim of this study is therefore to try to understand how lay people understand the term.

The psychological literature on fun is very limited, and occasionally psychologists have noted that certain concepts never seem to appear within psychological studies. Argyle [11] kept a list of such words which indeed included "fun". Furnham [12] pointed out that fortitude was such a word, and until recently this was also true of stoicism [13]. As far as we know, no psychology text book has fun in its index. Perhaps other synonyms are used in its place? There seems two literatures which contain concepts near to that of the fun concept. The first is from the work on motivation. The concept of intrinsic motivation captures some of the theme of fun [14], with the idea that some people are motivated to do something (usually work) because of the sheer enjoyment or fun of the activity itself. The activity or task is its own reward requiring no other reward such as approval, money or social contact. Words used in this regard for intrinsic motivation include hedonistically satisfying, optimally arousing and deliciously complex [15].

The second area of research where the concept of fun might appear is the research on positive psychology and happiness [16,17]. Early studies on the components of happiness mentioned various concepts like joy, hope, and flow, which were often considered to be the emotional side of happiness. For some joy was the opposite of depression [18]. Equally those working on the emotions have suggested a two orthogonal factor model, for which the first dimension is happy-sad and the other excited-relaxed [19]. Various writers have specified different types of happiness, some more akin to fun than others. Seligman [20] distinguished between a pleasant, engaged, good and meaningful life, while Morris [21] distinguished between seventeen types of happiness, including cerebral, tranquil and chemical happiness. Fun appears to be close to Seligman's pleasant-happiness and Morris' sensual, fantasy or comic happiness [22].

Only in a very occasional set of studies is there a direct confrontation with the nature of fun and its definition. As can be seen the concept is rarely well defined, and often a priori theoretical assumptions are made about its nature. In an extensive qualitative study entitled "How rural low-income families have fun" [23], the authors consistently use the word "fun" in quotes, thereby emphasising its theoretical difficulty, while acknowledging that in their study it is hard to differentiate from leisure, such that "the mothers" definitions and connotations of the word "fun" might not be congruent with research-based definitions", after which no further definition is either provided or emerges from the grounded theory analysis. Likewise the opening line of the analysis by Garn and Cothran [24], entitled "The fun factor in physical education", also puts fun in quote marks, saying how "both students and teachers rate "fun" at or near the top of their lists of goals for physical education". After reviewing several studies in physical education they eventually conclude only that, "the fun construct is a complex one consisting of a variety of factors ... without a solid conceptual framework". Similarly, Jackson [25], in an article entitled, "Joy, fun and flow state in sport", comparing various positive experiences associated with sport, comments, "Fun at first seems a more straightforward concept than joy, especially in sport, where the term is used so often. Everyone knows what fun is, right? But getting beyond 'sport is fun' is not easy.” The remainder of that paper then concentrates almost entirely on flow states, concluding eventually only that, "flow is key to understanding the joy, happiness, fun and enjoyment in sport... Not [though] that flow is the only path to these experiences". Finally, Middleton, who has published on the role of the importance of "academic fun" for gifted children [26], somewhat begs all the theoretical questions about the nature of fun when in a later paper he states at the very beginning that, "throughout this paper, I use the terms 'intrinsic motivation' and 'fun' interchangeably. The colloquial term 'fun' is better understood by students and teachers (and researchers), and carries connotations of positive affect that 'intrinsic motivation' may not” [27]. This forces fun into the conceptual mould of intrinsic motivation, while accepting that that may not be how participants themselves understand it. Together these four papers show the lack of conceptual clarity in the literature concerning the nature of fun, and yet show both the central relevance of the concept to lay thought and motivation, and the need to address the concept directly, rather than by assuming that it necessarily relates to some other 
single theoretical concept already described within psychology such as leisure, flow or intrinsic motivation.

The only (unpublished) study we have been able to find that asks directly about what experiences are actually included under the heading of fun, is that of Slaughter [28] who asks directly about a range of activities and makes conclusions both about fun people and fun experiences, suggesting that a high fun person is, "is a hedonist--an active, aggressive, impulsive adventurer who does not require intellect or sensitivity to himself or those around him", whereas a fun experience, "is likely to be an Affective or Sensori-Motor experience and less likely a Cognitive experience. It is about equally likely to be Cooperative or Solitary in nature and less likely to be a Competitive activity". The present study takes the nature of fun and its potential variability between individuals, as the central question that needs to be asked, acknowledging the potentially multi-faceted nature of the term.

In this paper we wish to describe an exploratory study of what a large group of adults think of fun and its nature. The study had multiple objectives, and in the paper we will describe them in the following order. Firstly, we provide a taxonomy of the types of activities or experiences that people include under the heading of fun, and secondly we examine how the various types of fun experience chosen are related to demographic factors such as age, sex and social class; to personality; and to education and particularly to science education (and in previous studies we have found that studying science is associated with different cultural and aesthetic activities and hence it seems at least possible that they are will also be related to fun [29]). Thirdly, we assessed how attitudes to fun differ, where attitudes refers to people's beliefs about how best to achieve fun and the extent they seek it our under different conditions, and we then looked at how such attitudes relate to the various background factors. Finally, we asked how the types of fun and also attitudes towards fun related to participation in a range of cultural and aesthetic activities that we have studied extensively before, and which are often described as being done for fun [30]. This is inevitably an exploratory study, but it is in the research tradition on lay theories of happiness [31-33], but this time looking at fun.

\section{Method}

The data in this study were collected as part of a large undergraduate laboratory class at University College London (UCL). The class in its present format has now been running for several years, and studies from previous years, on other topics, have been published elsewhere $[25,30,34]$.

\subsection{The Lab Class}

The class runs for three successive weeks, and introduces students to different research methods for studying attitudes. The topic is purposely only vaguely defined, and often is one with little formal research in the psychological literature, encouraging students to explore the richness of the question, and to follow their own directions. For the January 2008 class the topic was simply, "Fun".

The class was split into ten groups of about ten students who worked together for three full days over successive weeks, in conjunction with a demonstrator. In week 1 students ran small focus groups to explore the issues and attitudes, and the groups then chose two interviewees who were likely to be informative about the issues. The semi-structured interviews were transcribed it in a standard fashion, and students had access to all interviews carried out by all groups, and they used those interviews as a resource for writing questions for the quantitative questionnaire study.

The main part of the questionnaire consisted of a folded sheet of A3 paper (i.e. 4 A4 sheets), the middle two pages of which contained 40 attitude questions written by the students to a pre-defined rubric, each group providing four questions. The questionnaire was assembled at the end of Week 2, and each student collected 12 copies which they distributed to participants (see below). The data were entered into an SPSS data file which was analysed during week 3 . For the present analysis, only the quantitative data will be considered although it is important to remember that the breadth and quality of the attitude questions derives in large part from the in-depth qualitative research carried out beforehand.

\subsection{The Questionnaire}

This consisted of four printed pages. Page 1 contained eleven standard questions on demographics, education and social background. Pages 2 and 3 contained the forty attitude questions written by the students, and Page 4 contained a specially written question on a fun situation (see below), a set of twenty questions on participation in a range of cultural and aesthetic activities, which were extended from a set used in our previous study [30], and a brief measure of the Big Five personality dimensions which we have used in previous studies $[30,34,35]$, and has three items on each of the five factors (see http://www.ucl.ac.uk/medical-education/resources/questionnaires for details). Alpha reliabilities for Neuroticism, Extraversion, Openness to Experience, Agreeableness and Conscientiousness were .561, .590, $.611, .505$ and .541 , which are comparable to previous values, and, as we have argued elsewhere, are more than adequate for surveys with large samples such as 
the present one [30,36], where the interest is primarily correlational. Means (SDs) were 8.40 (2.37), 10.73 (2.16), 10.44 (2.56), 12.08 (1.98) and 10.45 (2.35) respectively.

\subsection{Question on a Fun Situation}

This question was written specially for the study, and began by asking participants to, "Think of a typical situation when you were having fun. Please describe it in three or four words". The question then continued, "Now, ring any of the [forty-two] words below that describe your feelings in that situation", after which followed the alphabeticised list of adjectives shown in Table 1. Although original, the questionnaire was inspired by previous adjective checklists in other situations [37-39], and in particular the study of Dubé and Le Bel [40] on the nature of pleasure.

\subsection{Participants}

Each undergraduate in the class was asked to find 12 participants who would complete the questionnaire, and it was said that these should broadly be "students", with the term not being rigorously defined, the only requirement being that respondents were aged 18 or over, and in some sense were or had been students. A stratified sampling scheme was used, each undergraduate obtaining completed questionnaires from 3 male participants who broadly could be regarded as scientists, 3 female participants who were scientists, 3 male participants who were not scientists, and 3 female participants who were not scientists. Apart from the stratification, students in the class were asked to be as wide-ranging as possible in finding the participants, with it being emphasised that participants need not just be from UCL, but could include friends, relations and colleagues, and they specifically should not be psychology undergraduates at UCL. The intention was therefore to obtain a large convenience sample for the purposes of data exploration. There was no expectation that the sample should be representative of the population as a whole, and the present paper should be interpreted with that limitation in mind. The data however are probably adequate for exploring the inter-relationships and correlations between measures, but care should be taken in the interpretation of absolute percentages and means. Although it might be a concern with our sampling method that some data may have been fabricated, or that some subjects may inadvertently have been included twice, a previous analysis [30] has shown that not to be the case, and there was no reason to believe either could be the case in the present study.

\subsection{Statistical Analysis}

Statistical analyses used SPSS v13.0.
Table 1. The first column shows the descriptors used for the fun situation, and the last column shows the overall percentage of respondents including the descriptor. The middle five columns show the loadings on the five varimax-rotated factors, sorted by size and with loadings less than 0.2 set as blank. Loadings greater than .4 are in bold. Descriptors in the questionnaire itself were in alphabetical order

\begin{tabular}{|c|c|c|c|c|c|c|}
\hline Facto & 1 & 2 & 3 & 4 & 5 & \\
\hline Descriptor & $\begin{array}{l}\text { Socia- } \\
\text { bility }\end{array}$ & $\begin{array}{c}\text { Con- } \\
\text { tentment }\end{array}$ & $\begin{array}{c}\text { Achieve- } \\
\text { ment }\end{array}$ & Sensual & Ecstatic & $\%$ \\
\hline joking & 0.678 & - & - & - & - & $43.8 \%$ \\
\hline laughing & 0.602 & - & - & - & - & $62.2 \%$ \\
\hline talking & 0.568 & 0.231 & - & - & - & $40.3 \%$ \\
\hline entertained & 0.514 & - & - & - & - & $51.6 \%$ \\
\hline witty & 0.489 & - & - & - & - & $25.0 \%$ \\
\hline spontaneous & 0.455 & - & - & - & 0.218 & $37.8 \%$ \\
\hline playful & 0.455 & - & - & - & 0.258 & $43.2 \%$ \\
\hline happy & 0.349 & 0.272 & - & - & - & $71.8 \%$ \\
\hline $\begin{array}{l}\text { self- } \\
\text { confident }\end{array}$ & 0.338 & - & 0.227 & - & - & $34.0 \%$ \\
\hline public & 0.249 & - & 0.202 & - & - & $12.1 \%$ \\
\hline peaceful & - & 0.569 & - & - & - & $17.4 \%$ \\
\hline warm & 0.235 & 0.499 & - & - & - & $26.5 \%$ \\
\hline relaxed & 0.283 & 0.476 & - & - & - & $46.6 \%$ \\
\hline loving & 0.256 & 0.463 & - & 0.256 & - & $26.3 \%$ \\
\hline caring & 0.220 & 0.459 & - & - & - & $16.0 \%$ \\
\hline contented & 0.200 & 0.445 & - & - & - & $36.4 \%$ \\
\hline blissful & - & 0.409 & - & - & 0.212 & $15.4 \%$ \\
\hline fulfilled & - & 0.380 & 0.354 & - & - & $28.6 \%$ \\
\hline stress free & 0.298 & 0.363 & - & - & - & $47.9 \%$ \\
\hline private & - & 0.336 & - & 0.269 & - & $8.6 \%$ \\
\hline joyful & 0.247 & 0.331 & - & - & 0.278 & $44.0 \%$ \\
\hline lazy & - & 0.246 & - & - & - & $8.2 \%$ \\
\hline focused & - & - & 0.638 & - & - & $18.8 \%$ \\
\hline challenged & - & - & 0.616 & - & - & $22.6 \%$ \\
\hline accomplished & - & - & 0.458 & - & - & $12.0 \%$ \\
\hline absorbed & - & - & 0.448 & - & - & $28.7 \%$ \\
\hline engrossed & - & - & 0.414 & - & - & $17.5 \%$ \\
\hline inspired & - & 0.296 & 0.403 & - & - & $21.1 \%$ \\
\hline proud & - & - & 0.380 & - & - & $13.8 \%$ \\
\hline nervous & - & - & 0.369 & - & - & $6.9 \%$ \\
\hline fearful & - & - & 0.293 & - & - & $4.9 \%$ \\
\hline amazement & - & - & 0.293 & - & 0.200 & $15.5 \%$ \\
\hline surprised & - & - & 0.228 & - & - & $9.5 \%$ \\
\hline sensual & - & - & - & 0.661 & - & $9.3 \%$ \\
\hline lustful & - & - & - & 0.502 & - & $8.7 \%$ \\
\hline intimate & - & 0.318 & - & 0.501 & - & $13.4 \%$ \\
\hline romantic & - & 0.243 & - & 0.480 & - & $10.7 \%$ \\
\hline vulnerable & - & - & 0.231 & 0.306 & - & $4.4 \%$ \\
\hline ecstatic & - & - & - & - & 0.560 & $20.6 \%$ \\
\hline crazy & 0.205 & - & - & - & 0.487 & $27.1 \%$ \\
\hline excited & 0.234 & - & 0.312 & - & 0.486 & $47.7 \%$ \\
\hline energetic & 0.282 & - & - & - & 0.439 & $47.6 \%$ \\
\hline
\end{tabular}




\section{Results}

Questionnaires were completed by 1100 respondents, of whom 1088 gave their sex (males $n=534,49.1 \%$; female $\mathrm{n}=554,50.9 \%$ ), with an age range of 18 to 78 (mean $=25.5$, median $=21, \mathrm{SD}=10.71$, quartiles 20 25), with $142(12.9 \%)$ of the respondents being aged over 40. 964 subjects indicated that they were studying for or had obtained a degree, and the subjects self-classified subjects according to the 13 categories used by UCAS, and arbitrarily, but in a similar way to previous studies [29;30], we classified Medical Science, Biological science, Physical science, Mathematics and Engineering as science subjects. On that basis, 38.9\% of respondents (375/964) were studying science.

Social class was assessed on the occupations of each parent, based on the five-point Registrar-General's scale, with class overall defined as the higher of the two parents' occupations, scored I $=5, \mathrm{II}=4, \mathrm{III}=3$, $\mathrm{IV}=2$ and $\mathrm{V}=1$, so that high scores correlated with higher social class. Overall, of 1031 respondents, 515 (50.0\%) were from social class I, 306 (29.7\%) from class II, 153 (14.8\%) from class III, 35 (3.4\%) from class IV, and 22 (2.1\%) from class V.

\subsection{The Fun Situation and Types of Fun}

All but 48 subjects described a situation in which they had recently been having fun, Of the 42 adjectives describing the situation, 40 subjects ticked none of them, and one ticked all 42, and these 41 subjects were removed from further analysis. Table 1 shows the overall proportion of respondents ticking each of the adjectives. Factor analysis was carried out using principal axis factoring with varimax rotation. A scree-slope analysis suggested that there were five factors (the first ten eigenvalues being 6.22 , 3.33, 2.55, 1.88, 1.37, 1.27, 1.22, 1.17, 1.05 and 1.01), with reliabilities of .745, .773, .800, .701 and .764 respectively. The factor structure shown in Table 1 is very clear. Scores were extracted for each factor. To aid in describing the factors, participants were identified who had a loading of below zero on four of the five factors, and the descriptions then examined for those with the highest loadings on the remaining fifth factor.

- Fun type 1 can be described as Sociability, with large loadings on joking, laughing, talking, and entertainment, with high scorers describing the situation as "socializing with friends", "hanging out with friends", "enjoy, relaxed, excited”, "Being with friends", "out with friends", "socialising with friends", "when I'm with the girls", "board game with friends ", "drunken sports night with friends", and "out with friends".

- Fun type 2 can be labelled as Contentment, with its loadings on peaceful, warm, relaxed, loving, caring, and contentment. High scoring situations were "gardening", "just being at home", "went to Southampton beach", "being with people I like", "swimming", "with friend, in fave cafe, study", "chatting with mates", "smiley laughing content", "swimming in the sea" and "listening to music".

- Fun type 3 can be labelled as Achievement, with high loadings on focussed, challenged, accomplished, absorbed and engrossed, and contains some sense of a flow state. High scoring situations included, "acting in a play ", "playing football with friends", "working on my GPS tracer project", "winning in a game", "horse riding", "computer games with friends", "jamming with friends", "when I was creating something ", "when learning something interesting", "achieving a goal", and "racing, mountain, skis, speed".

- Fun type 4 is labelled Sensual, but might also be labelled romantic or sexual with its loadings on sensual. lustful, intimate and romantic. Relatively few participants scored highly on this factor but amongst those who did the descriptions were "having sex" (reported by three participants), "food and good company", and "spending time with my boyfriend".

- Finally, fun type 5 is readily described as Ecstatic, with loadings on ecstatic, crazy, excited and energetic. Typical situations were "amusement parks", "Exhilarating, exciting, unpredictable, amusing", "partying, drinking, watching films", "going clubbing", "clubbing with friends", "elation euphoria enjoy”, "clubbing”, "pub/clubbing”, "visiting night clubs", and "at a rave".

\subsection{Correlates of Fun Types}

Table 2 shows correlations of scores on the five fun types in relation to demographic factors (age, sex, science education and father's social class), and to the big five personality factors. Overall women reported more fun situations involving sociability, and contentment, and less with achievement, and older respondents reported more fun involving contentment and achievement, and less sociability, sensual or ecstatic fun. Neither social class nor a science education related to the type of run reported. Personality showed several very significant associations, and considering only those with $\mathrm{p}<.001$, extraversion was associated with sociability and ecstatic fun, agreeableness with more fun involving sociability and less that was sensual, and openness to experience with more fun involving achievement. Neither neuroticism nor conscientiousness showed correlations at the $p<.001$ level with the types of fun. 
Table 2. Correlates of scores on the five fun types in relation to background variables and personality. Ns vary from 964 to 1059. Key: * $\mathbf{p}<.05 ; * * \mathbf{p}<.01$; ${ }^{* * *} \mathbf{p}<.001$. Correlations greater than .1 are in bold

\begin{tabular}{lccccc}
\hline \multirow{2}{*}{ Fun type } & 1 & 2 & 3 & 4 & 5 \\
\cline { 2 - 6 } & Sociability & $\begin{array}{c}\text { Content- } \\
\text { ment }\end{array}$ & $\begin{array}{c}\text { Achieve- } \\
\text { ment }\end{array}$ & Sensual & Ecstatic \\
\hline Female & $0.067^{*}$ & $0.084^{* *}$ & $-\mathbf{0 . 1 1 5 * * *}$ & -0.033 & -0.001 \\
Age & $-0.062^{*}$ & $0.083^{* *}$ & $0.071^{*}$ & -0.052 & $-\mathbf{0 . 1 5 9 * * *}$ \\
Science & 0.016 & 0.009 & 0.036 & -0.047 & 0.030 \\
education & 0.040 & -0.057 & 0.006 & -0.035 & 0.052 \\
Social class & 0.028 & $-0.065^{*}$ & -0.014 & 0.022 & $0.097^{* *}$ \\
Neuroticism & $0.050^{*}$ & -0.028 & $0.081^{* *}$ & $\mathbf{0 . 2 5 3 * * *}$ \\
Extraversion & $\mathbf{0 . 1 9 0 * * *}$ & $-0.060^{*}$ & \\
Openness & 0.053 & $0.081^{* *}$ & $\mathbf{0 . 1 4 8 * * *}$ & 0.014 & 0.054 \\
Agreeableness & $\mathbf{0 . 1 8 7 * * *}$ & $0.062^{*}$ & 0.016 & $-\mathbf{0 . 1 0 1} * * *$ & 0.004 \\
Conscientious- & 0.040 & 0.049 & 0.055 & $-0.061^{*}$ & 0.000 \\
ness & & & & & \\
\hline
\end{tabular}

\subsection{Attitudes towards Fun}

The forty attitude questions were factor analysed using principal axis factoring, followed by varimax rotation and factor score extraction. The scree slope suggested five main factors, with first ten eigenvalues being 4.03, $3.16,1.95,1.73,1.47,1.39,1.37,1.23,1.12$ and 1.09 . The five factors, which had reliabilities of respectively $.800, .778, .655, .700$ and .725 , were identified as follows:

- Fun attitude 1 which was labelled Risk-taking. Participants with high scores tended to agree with questions asking, "Are you willing to take risks to have fun?", "Would you repeat a certain activity that carried a health risk in order to have fun?", "Can you have fun when you are scared?", "Would you consider breaking the law to have fun?" and "Is an activity more fun if there is risk involved?”.

- Fun attitude 2 was the most difficult to label. High scorers tended to agree with questions asking, "Is it important to have a similar personality as people in order to have fun with them?", "Is the presence of other people essential to have fun?", "Do extraverted people have more fun than introverted people?”, and disagreed with the question, "Is it possible to have fun by yourself?". The main thrust seems to be on fun as a sociable activity, dependent on particular types of other people, and it was therefore labelled Fun people.

- Fun attitude 3 was characterised by participants agreeing with questions that asked, "Is fun one of the requirements we ought to fulfil in life?", "Do you think you need to have fun to be happy?”, "Does having fun always involve happiness?", "Can fun provide you with happiness in the long-term?" and "Does unhappiness restrict your ability to have fun?”. Fun and happiness seem here to be causally related, and the factor was labelled Fun causing happiness.

- Fun attitude 4 was straightforward, with those scoring highly agreeing to questions that asked, "Do rich people have more fun?", "Do you have more fun if you spend more money?" and "Do you think the amount of money that you have influences how much fun you have?". This can be labelled as Money.

- Finally, fun attitude 5 was characterised particularly by answering Yes to the two questions, "Are unplanned activities more fun than planned ones?" and "Is spontaneous fun more enjoyable than planned fun?”. This can be labelled as Spontaneity.

\subsection{Correlates of Fun Attitudes}

The five fun attitudes were correlated with the demographic and personality variables used earlier, and with the fun types which had been identified (Table 3). For simplicity, only correlations significant with $p<.001$ will be considered. Female participants were less likely to consider risk-taking as important in having fun, as also were older subjects, who also thought that fun people were less important. Neither a science education nor social class related to the attitudes towards fun.

Personality showed strong correlations with attitudes towards fun. Extraverts saw risk-taking, fun people and spontaneity as important, whereas while those with greater openness to experience also saw risk-taking as important, they also saw both fun people and money as unimportant. Agreeable individuals saw fun people and money as unimportant in having fun, whereas they did see fun as causing happiness. Finally, participants with higher neuroticism scores saw fun people as important to having fun.

Attitudes to fun correlated with types of fun in straightforward ways. Those describing sociable types of fun, saw risk-taking as important to fun, and fun as causing happiness.

Those describing contentment as fun saw risk-taking as unimportant, and those describing achievement in their fun seeing fun people as unimportant to having fun. Sensual types of fun were associated with money as being important, and those describing ecstatic fun types saw risk-taking as important, and fun as causing happiness.

\subsection{Cultural and Aesthetic Correlates}

If attitudes towards fun differ between people, and 
Table 3. Correlates of scores on the five fun attitudes in relation to background variables and personality. Ns vary from 964 to 1059. Key: $* \mathbf{p}<.05 ; * * \mathrm{p}<.01 ; * * * \mathrm{p}<.001$. Correlations greater than .1 are in bold

\begin{tabular}{|c|c|c|c|c|c|}
\hline \multirow{2}{*}{ Fun attitude } & 1 & 2 & 3 & 4 & 5 \\
\hline & Risk taking & Fun people & Fun causing happiness & Money & Spontaneity \\
\hline Female & $-0.159 * * *$ & 0.053 & 0.011 & $-0.064^{*}$ & -0.037 \\
\hline Age & $-0.254^{* * *}$ & $-0.131 * * *$ & -0.049 & -0.014 & 0.036 \\
\hline Science education & 0.021 & -0.042 & 0.030 & -0.033 & -0.059 \\
\hline Social class & $0.075^{*}$ & 0.032 & 0.000 & -0.050 & 0.021 \\
\hline Neuroticism & -0.015 & $0.144 * * *$ & 0.007 & $0.080^{* *}$ & 0.048 \\
\hline Extraversion & $0.255^{* * *}$ & $0.099 * *$ & $0.247 * * *$ & 0.005 & $0.118 * * *$ \\
\hline Openness & $0.193^{* * *}$ & $-0.175^{* * *}$ & -0.039 & $-0.128 * * *$ & 0.036 \\
\hline Agreeableness & $-0.104^{* *}$ & $-0.150 * * *$ & $0.142 * * *$ & $-0.161^{* * *}$ & 0.046 \\
\hline Conscientiousness & $-0.164 * * *$ & $-0.074 *$ & 0.004 & 0.029 & -0.041 \\
\hline Fun type 1: Sociability & $\left.0.129\right|^{* * *}$ & $-0.080^{* *}$ & $0.164 * * *$ & -0.045 & $0.099 * *$ \\
\hline Fun type 2: Contentment & $-0.125 * * *$ & $-0.098^{* *}$ & -0.059 & $-0.062 *$ & -0.030 \\
\hline Fun type 3: Achievement & $0.101 * *$ & $-0.133^{* * *}$ & -0.041 & 0.040 & $-0.079 * *$ \\
\hline Fun type 4: Sensual & $0.092^{* *}$ & $0.068^{*}$ & 0.019 & $0.132 * * *$ & $0.075^{*}$ \\
\hline Fun type 5: Ecstatic & $0.202^{* * *}$ & $0.072 *$ & $0.178^{* * *}$ & 0.028 & $0.083 * *$ \\
\hline
\end{tabular}

people typically derive fun from different activities, then it would be expected that there would be correlations with involvement in differing cultural and aesthetic activities. Table 4 shows correlation between the types of fun and attitudes towards fun, and twenty activities. There are 23 correlations which are significant with $\mathrm{p}<.001$, and without considering all in detail, there are several interesting patterns. Only a few correlations are with the fun types although they do make sense, dancing being associated with sociability and ecstatic types of fun, whereas classical music is associated with lower sociability and higher fun from achievement, whereas pop music is associated with less fun from achievement. Amongst the attitudes, risk taking is associated not only with pop concerts and popular music and dancing, but also with museums and art galleries and with drawing and painting. Attitudes towards fun people are associated with pop concerts and discos, dancing, going to cinemas, and browsing the internet, and negatively with listening to classical music and reading novels. The attitude that fun causes happiness has a similar pattern of correlations, being positively associated with popular music, concerts, discos and dancing, and negatively associated with classical music. The importance of money for fun was associated positively with browsing the internet and negatively with reading novels. Fun in relation to spontaneity did not relate to any of the aesthetic activities.

\section{Discussion}

"Whatever we do, we have to make it fun", has become a modern truism and a modern cliche, applied to everything from teaching children modern languages, to playing sport, or encouraging people to eat more fruit and vegetables. Fun however differs for different people, as was well seen in an interview with the new Registrary (the Senior Administrative Officer) of the University of Cambridge, who, when talking about the nature of academic work, said, "Fun is a word I use", adding, "not frivolous fun though. We all spend a lot of time at work and we should make people feel they have achieved something each day and enjoy the companionship and social interaction" [41]. As Harvey [42] has put it, "having fun at work is serious business".

However widely used is the word "fun", and however superficially attractive it is to invoke it as a universal panacea for solving problems in life, what rapidly becomes obvious is that any statement invoking fun will inevitably beg the question of what fun is, and how fun will be recognised, and for whom. For psychologists this means attempting to provide an operational definition. What the present study makes very clear is that fun is not a simple concept. If fun is a requirement in education or other activities then some answer is required as to whose type of fun it should be. The problem is perhaps well seen in the 1994 film Fun (directed by Rafael Zielinksi), which is described by the website $w w w . i m d b . c o m$ as "Two misfit girls meet, make friends and decide to kill an elderly woman just for fun" (our emphasis), and in the section of the website marked, "Fun stuff" [sic], under Quotes, is the dialogue, "I told you. Hilary and I killed the old lady just for fun. What, you want me to yell it out loud or something?" If, as seems clear, different people see fun in different ways and in different types of activity (and for some people, as a character in Fun puts it, "fun is not number one"), then any prescriptive attempt to 
Table 4. Correlates of scores on the five fun types and the five attitudes to fun, in relation to the amount of time spent on various cultural and aesthetic activities. Ns vary from 1051 to 1059 . Key: $*^{*}<.05$; $* *$ p $<.01$; $* * *$ p $<.001$. Correlations greater than .1 are in bold

\begin{tabular}{|c|c|c|c|c|c|c|c|c|c|c|}
\hline & \multicolumn{5}{|c|}{ Fun Type } & \multicolumn{5}{|c|}{ Fun Attitude } \\
\hline & 1 & 2 & 3 & 4 & 5 & 1 & 2 & 3 & 4 & 5 \\
\hline & Sociability & $\begin{array}{l}\text { Content- } \\
\text { ment }\end{array}$ & Achievement & Sensual & Ecstatic & Risk taking & Fun people & $\begin{array}{l}\text { Fun causing } \\
\text { happiness }\end{array}$ & Money & $\begin{array}{l}\text { Spont- } \\
\text { aneity }\end{array}$ \\
\hline Listen to popular music & $0.087^{* *}$ & $-0.076^{*}$ & $-0.118 * * *$ & 0.036 & 0.029 & $0.117 * * *$ & 0.033 & $0.235 * * *$ & 0.007 & 0.037 \\
\hline Listen to classical music & -0.040 & 0.052 & $0.113 * * *$ & -0.039 & -0.052 & 0.048 & $-0.149 * * *$ & $-0.122 * * *$ & $-0.084 * *$ & -0.031 \\
\hline Go to pop concerts/discos & 0.038 & $-0.080^{* *}$ & 0.014 & $0.096^{* *}$ & $0.092 * *$ & $0.285^{* * *}$ & $0.167 * * *$ & $0.121 * * *$ & 0.036 & 0.053 \\
\hline $\begin{array}{l}\text { Go to classical music con- } \\
\text { certs/ opera }\end{array}$ & $-0.118 * * *$ & 0.044 & $0.066^{*}$ & 0.015 & -0.039 & 0.032 & 0.043 & $-0.109 * * *$ & 0.038 & -0.046 \\
\hline Play a musical instrument & -0.034 & 0.007 & $0.082^{* *}$ & 0.008 & -0.015 & $0.095^{* *}$ & -0.029 & $-0.088 * *$ & -0.010 & $-0.065^{*}$ \\
\hline $\begin{array}{l}\text { Go to museums or art galler- } \\
\text { ies }\end{array}$ & 0.009 & 0.022 & 0.034 & 0.018 & 0.022 & $0.121 * * *$ & $-0.089 * *$ & -0.004 & -0.059 & -0.003 \\
\hline $\begin{array}{l}\text { Read about art in newspapers, } \\
\text { magazines or books }\end{array}$ & 0.005 & 0.036 & 0.018 & 0.048 & -0.017 & $0.097^{* *}$ & -0.048 & 0.005 & -0.041 & 0.016 \\
\hline Draw or paint & -0.026 & -0.024 & 0.014 & 0.058 & 0.000 & $0.127 * * *$ & -0.054 & -0.006 & -0.057 & -0.035 \\
\hline Read a novel & 0.056 & 0.038 & 0.065 & 0.008 & $-0.087^{* *}$ & 0.034 & $-0.171^{* * *}$ & -0.010 & $-0.129 * * *$ & -0.042 \\
\hline $\begin{array}{l}\text { Read non-fiction books (not } \\
\text { for work or study) }\end{array}$ & 0.011 & 0.028 & $0.063^{*}$ & 0.050 & 0.018 & $0.102^{* *}$ & $-0.086^{* *}$ & -0.059 & -0.047 & -0.004 \\
\hline Read poetry & $-0.067^{*}$ & $0.068^{*}$ & 0.054 & $0.089 * *$ & 0.006 & $0.073^{*}$ & -0.027 & $-0.099 * *$ & $-0.088^{* *}$ & 0.022 \\
\hline Go to the cinema & -0.015 & -0.019 & -0.057 & -0.009 & 0.042 & 0.038 & $0.167 * * *$ & $0.078^{*}$ & $0.062 *$ & -0.002 \\
\hline $\begin{array}{l}\text { Go to the theatres (plays/ } \\
\text { musicals, etc) }\end{array}$ & -0.002 & 0.010 & 0.014 & $0.064^{*}$ & 0.049 & 0.046 & 0.020 & -0.022 & 0.006 & -0.028 \\
\hline $\begin{array}{l}\text { Act or otherwise take part in } \\
\text { theatre }\end{array}$ & $-0.107^{* *}$ & -0.034 & -0.030 & $0.067 *$ & 0.004 & $0.072 *$ & $0.089 * *$ & -0.051 & -0.011 & -0.020 \\
\hline $\begin{array}{l}\text { Go to classical or modern } \\
\text { ballet / dance }\end{array}$ & $-0.062^{*}$ & 0.060 & -0.015 & $0.061^{*}$ & -0.013 & 0.006 & 0.046 & -0.041 & -0.016 & $-0.066^{*}$ \\
\hline Go dancing (any form) & $0.141 * * *$ & -0.058 & -0.050 & $0.102 * *$ & $0.164 * * *$ & $0.256^{* * *}$ & $0.115^{* * *}$ & $0.123^{* * *}$ & 0.007 & 0.044 \\
\hline Watch television & -0.018 & 0.015 & -0.015 & -0.012 & -0.010 & $-0.087 * *$ & $0.062^{*}$ & 0.058 & $0.066^{*}$ & -0.005 \\
\hline Listen to radio & $-0.075^{*}$ & -0.039 & 0.000 & $-0.062 *$ & -0.066 & -0.044 & -0.032 & 0.033 & -0.031 & -0.007 \\
\hline Listen to podcasts & -0.056 & $-0.075^{*}$ & -0.034 & -0.038 & 0.026 & 0.027 & $0.090 * *$ & -0.024 & 0.058 & -0.016 \\
\hline Browse the internet & -0.008 & $-0.070 *$ & $-0.064^{*}$ & 0.047 & $0.078^{*}$ & 0.044 & $0.135 * * *$ & 0.019 & $0.109 * * *$ & 0.019 \\
\hline
\end{tabular}

"make something fun" is as likely as not to mean that it will not be fun for some of those taking part. Anyone who as a child or an adult has cringed at being asked publically to take part in someone else's idea of fun which they find embarrassing or repellent will know the problem instantly. The invocation of fun is therefore not likely to be the simple panacea that its advocates might suggest, so that as always education any other activity has to provide for different people with different needs.

For an extravert a party maybe the essence of fun, while for a person high on Openness it maybe to a visit a science park, museum or gallery. Thus an agreeable, conscientious, female, middle-aged introvert may have a very different conception of fun from a young, neurotic, poorly educated, sensation-seeking male. Differential psychologists have argued that people seek out and change social activities that fit with their prefer- ences and values. Whilst that may not necessarily label all those preferred activities as fun, it is probably a component of them. In this sense fun activities may be defined as those which satisfy various specific psychological needs for the individual. This is why the term is both subjective and multifaceted. It may therefore be useful to think of types of fun either within the Big Five factor space of trait theories or within some specific needs hierarchy such as that suggested by Murray [43].

Fun can be seen as both an attribute of a person ("they are jolly good fun") and the property of an activity ("swimming is good fun"). The factor analysis of the fun descriptors suggests that they are being both to people and activities though some clearly fit the one better than the other. The first two factors were labelled sociability and contentment. Using personality terminology these could be interpreted in terms of stable 
extraversion. Indeed, in one of the very earliest books in the area Eysenck [44] argued that "happiness is stable extraversion". This assertion has been supported in many studies $[45,46]$. It is perhaps no surprise that participants' extraversion scores were strongly positively correlated with sociability.

In this study the sensual and ecstatic factors could also be applied to people, though achievement is usually thought of more as the property of an activity. Younger, agreeable, extraverted females associated fun most with merry-making sociability, while older, open males more with flow-type achievement activities. The fun-type factor that showed most correlations with individual differences was contentment. This form of warm relaxed fun was associated with being, female, open, agreeable, introverted and stable.

Participants' personality was also related in logical ways to the types of fun they reported. Thus young male extraverts high on openness (curiosity) but low on agreeableness and conscientiousness like risk-taking. This makes sense both in terms of the literature on personality correlates of dangerous sports and accidents $[47,48]$. Equally extraverts see spontaneity as an identifiable component of fun. Fun people it would appear are agreeable, open, extraverts. They would appear to have the greatest capacity for fun: seek it out, create it, enjoy it.

If one considers fun as primarily a characteristic of activities, behaviours or tasks then it appears to have various components, namely that it concerns other people in a calm, involved focused activity, as well as also being associated with physical intimacy and energetic excitement, particularly with respect to younger people. Fun thus has a cognitive dimension and an affective dimension. It can be both relaxed and exciting. The terms applied equally to both.

Attitudes towards fun are also multidimensional. $\mathrm{Pu}-$ ritans clearly disapprove of fun. Studies on the Protestant Work Ethic show that they also disapprove of any activity labeled "fun" because it may be seen as time-wasting and purposeless [49]. Fun still, for many, is seen as a temporary and frivolous consolation, the business of life being serious and earnest and having little room for trivialities like fun. Clearly personality and demography predicts attitudes to fun. Young male open extraverts are clearly interested in fast, risky activities which they label as fun. It is particularly interesting that neurotics associate fun with other people while those low on both Openness and Agreeableness do not. Thus while "hell is other people" may be true for the disagreeable individual with low Openness, less stable people may find others a useful source of help and support.

This study represents the beginning of a full exploration of an important and neglected psychological concept. For researchers it may even be suggested that researching fun can itself be rather a lot of fun.

\section{REFERENCES}

[1] C. D. Bryant and C. J. Forsyth, "The Fun God: Sports, Recreation, Leisure, and Amusement in the United States," Sociological Spectrum, Vol. 25, No. 2, 2005, pp. 197-211.

[2] A. E. Hamilton, "Psychology and 'the Great God Fun'," Julian Press, New York, 1955.

[3] E. R. Gritz, M. K. Tripp, A. S. James, R. B. Harrist, N. H. Mueller, R. M. Chamberlain, et al., "Effects of a Preschool Staff Intervention on Children's Sun Protection: Outcomes of Sun Protection is Fun!” Health Education and Behavior, Vol. 34, No. 4, 2007, pp. 562-577.

[4] R. Prigo, "Making Physics Fun: Key Concepts, Classroom Activities, and Everyday Examples, Grades K-8," Corwin Press, Thousand Oaks, 2007.

[5] T. Cook and E. Hess, "What the Camera Sees and from whose Perspective: Fun Methodologies for Engaging Children in Enlightening Adults," Childhood: A Global Journal of Child Research, Vol. 14, No. 1, 2007, pp. 29-45.

[6] G. Sim, S. MacFarlane and J. Read, “All Work and no Play: Measuring Fun, Usability, and Learning in Software for Children,” Computers and Education, Vol. 46, No. 3, 2006, pp. 235-248.

[7] C. Angell, O. Guttersrud, E. K. Henriksen and A. Isnes, "Physics: Frightful, but Fun: Pupils' and Teachers' Views of Physics and Physics Teaching," Science Education, Vol. 88, No. 5, 2004, pp. 683-706.

[8] M. Davis, T. Baranowski, K. Resnicow, J. Baranowski, C. Doyle, M. Smith, et al., "Gimme 5 Fruit and Vegetables for Fun and Health: Process Evaluation,” Health Education and Behavior, Vol. 27, No. 2, 2000, pp. 167-176.

[9] K. A. Kendall-Tackett, "How to Write for a General Audience: A Guide for Academics who Want to Share their Knowledge with the World and Have Fun Doing it," American Psychological Association, Washington, D.C., 2007.

[10] L. A. Hayduk and D. N. Glaser, "Jiving the Four-Step, Waltzing around Factor Analysis, and Other Serious Fun," Structural Equation Modeling, Vol. 7, No. 1, 2000, pp. 135.

[11] M. Argyle, "My Secret List (Personal Communication to Adrian Furnham)," 2000.

[12] A. Furnham, “Fortitude,” In: D. Anderson, Ed., The Loss of Virtue, Social Affairs Unit, London, 1992, pp. 137-153.

[13] A. Furnham, K. Petrides and S. Spencer-Bowdage, "The Effects of Different Types of Social Desirability on the Identification of Repressors,” Personality and Individual Differences, Vol. 33, No. 1, 2002, pp. 119-130.

[14] E. Deci and R. Ryan, "Intrinsic Motivation and Self-Determination in Human Behavior,” Plenum Publishing, New York, 2008.

[15] A. Furnham, "The Psychology of Behaviour at Work," Psychology Press, Hove, 2005.

[16] M. Argyle, “The Psychology of Happiness,” Routledge 
Publishing, London, 2001.

[17] D. Myers, “The Pursuit of Happiness,” Avon Publications, New York, 1992.

[18] A. Wessman and D. Ricks, “Mood and Personality,” Holt, Rinehart \& Winston, New York, 1966.

[19] J. Russell, “A Circumplex Model of Affect,” Journal of Personality and Social Psychology, Vol. 39, No. 6, 1980, pp. 1161-1178.

[20] M. Seligman, “Authentic Happiness,” Random House, London, 2003.

[21] D. Morris, “The Nature of Happiness,” Little Books, London, 2004.

[22] A. Furnham and I. Christoforou, "Personality Traits, Emotional Intelligence, and Multiple Happiness,” North American Journal of Psychology, Vol. 9, No. 3, 2007, pp. 439462.

[23] S. L. Churchill, V. L. Plano-Clark, K. Prochaska-Cue, J. W. Creswell and L. Ontai-Grzebik, "How Rural Low-Income Families Have Fun: A Grounded Theory Study,” Journal of Leisure Research, Vol. 39, No. 2, 2007, pp. 271-294.

[24] A. C. Garn and D. J. Cothran, “The Fun Factor in Physical Education," Journal of Teaching in Physical Education, Vol. 25, No. 3, 2006, pp. 281-297.

[25] S. A. Jackson, “Joy, Fun, and Flow State in Sport,” In: Y. L. Hanin, Ed., Emotions in Sport, Human Kinetics Publishers, Champaign, 2000, pp. 135-155.

[26] J. A. Middleton, J. Littlefield and R. Lehrer, “Gifted Students' Conceptions of Academic Fun: An Examination of a Critical Construct for Gifted Education,” Gifted Child Quarterly, Vol. 36, No. 1, 1992, pp. 38-44.

[27] J. A. Middleton, "A Study of Intrinsic Motivation in the Mathematics Classroom: A Personal Constructs Approach,” Journal for Research in Mathematics Education, Vol. 26, No. 3, 1995, pp. 254-279.

[28] D. C. Slaughter, "A Fun Scale and its Possible Applications,” Dissertation Abstracts International, Vol. 44, 1984, pp. 3577-3578.

[29] I. C. McManus, "Measuring the Culture of C. P. Snow's Two Cultures," Empirical Studies of the Arts, Vol. 24, No. 2, 2006, pp. 219-227.

[30] I. C. McManus and A. Furnham, “Aesthetic Activities and Aesthetic Attitudes: Influences of Education, Background and Personality on Interest and Involvement in the Arts," British Journal of Psychology, Vol. 97, No. 4, 2006, pp. 555-587.

[31] A. Furnham and H. Cheng, "Lay Theories of Happiness," Journal of Happiness Studies, Vol. 1, No. 2, 2000, pp. 227-246.

[32] A. Furnham, H. Cheng and Y. Shirasu, "Lay Theories of Happiness in the East and West," Psychologia, Vol. 44, No. 2, 2001, pp. 173-187.

[33] J. Pflug, “Folk Theories of Happiness,” Social Indicators Research, Vol. 92, No. 3, 2009, pp. 551-563.
[34] A. Furnham, I. C. McManus and D. Scott, "Personality, Empathy and Attitudes to Animal Welfare," Anthrozoös, Vol. 16, No. 2, 2003, pp. 135-146.

[35] A. Furnham and I. C. McManus, "Student Attitudes to University Education,” Higher Education Review, Vol. 36, No. 2, 2004, pp. 29-38.

[36] R. A. Fox, I. C. McManus and B. C. Winder, "The Shortened Study Process Questionnaire: An Investigation of its Structure and Longitudinal Stability Using Confirmatory Factor Analysis,” British Journal of Educational Psychology, Vol. 71, No. 4, 2001, pp. 511-530.

[37] C. Mackay, T. Cox, G. Burrows and T. Lazzerini, "An Inventory for the Measurement of Self-Reported Stress and Arousal," British Journal of Social and Clinical Psychology, Vol. 17, No. 3, 1978, pp. 283-284.

[38] G. Matthews, D. M. Jones and A. G. Chamberlain, "Refining the Measurement of Mood: The UWIST Mood Adjective Checklist,” British Journal of Psychology, Vol. 81, 1990, pp. 17-42.

[39] T. J. Huelsman and R. C. Nemanick, "Scales to Measure Four Dimensions of Dispositional Mood: Positive Energy, Tiredness, Negative Activation, and Relaxation," Educational and Psychological Measurement, Vol. 58, No. 5, 1998, pp. 804-819.

[40] L. Dubé and J. L. Le Bel, "The Content and Structure of Laypeople's Concept of Pleasure,” Cognition and Emotion, Vol. 17, No. 2, 2003, pp. 263-295.

[41] Anonymous, "Creating a Culture of Change (Interview with Dr. Jonathan Nicholls)," CAM: The University of Cambridge Alumni Magazine, No. 53, 2008, p. 9.

[42] A. Gostick and S. Christopher, "Having Fun at Work is Serious Business,” PsycCRITIQUES, Vol. 53, No. 41, 2008, pp. 1-3.

[43] H. A. Murray, "Explorations in Personality,” Oxford University Press, Oxford, 1938.

[44] H. J. Eysenck, "I Do: Your Guide to a Happy Marriage,” Century Publishing, Post Falls, 1983, pp. 1-217.

[45] L. J. Francis, L. B. Brown, D. Lester and R. Philipchalk, "Happiness as Stable Extraversion: A Cross-Cultural Examination of the Reliability and Validity of the Oxford Happiness Inventory among Students in the U.K., U.S.A., Australia, and Canada," Personality and Individual Differences, Vol. 24, No. 2, 1998, pp. 167-171.

[46] A Furnham and C. Brewin, "Personality and Happiness," Personality and Individual Differences, Vol. 11, No. 10, 1990, pp. 1093-1096.

[47] M. Zuckerman, "P-Impulsive Sensation Seeking and its Behavioral, Psychophysiological Biochemical Correlates," Neuropsychobiology, Vol. 28, No. 1-2, 1993, pp. 30-36.

[48] M. Zuckerman, "Behavioral Expressions and Biosocial Bases of Sensation Seeking,” Cambridge University Press, Cambridge, 1994.

[49] A. Furnham, “The Protestant Work Ethic,” Routledge Publishing, Cornwall, 1990. 